\title{
Rubinstein Taybi Syndrome
}

\author{
Das $\mathbf{N}^{1}$, Ghosh $\mathbf{N}^{2}$, Biswas $\mathrm{S}^{3}$, Nayek $\mathrm{K}^{4}$ \\ ${ }^{1}$ Dr. Nabanita Das, MBBS, MD Resident, ${ }^{2}$ Dr. Nilanjan \\ Ghosh, MBBS, MD, Residential Medical Officer cum \\ Clinical Tutor, ${ }^{3} \mathrm{Dr}$. Soumyadeep Biswas, MBBS, MD \\ Resident, ${ }^{4}$ Dr. Kaustav Nayek, Professor. All from the \\ Department of Paediatrics, R.G Kar Medical College, \\ Kolkata, West Bengal, India.
}

\section{Introduction}

$\mathrm{R}^{\mathrm{s}}$ ubinstein-Taybi is a rare genetic syndrome ${ }^{1}$ characterised by distinctive facies, microcephaly, mental retardation, broad thumb and great toe with other abnormalities. Diagnosis is mainly clinical. Incidence is 1:100000-125000 at birth². In 1963 this syndrome was first described by Rubinstein and Taybi ${ }^{1}$.

\section{The Case}

A two and a half year old Muslim female child, born out of nonconsanguinous marriage, presented with complaints of inability to walk and speak. She is the first child of the parents. She could only stand with support, produce some incomprehensible sounds. There is past history of frequent cough and cold with ear discharge, recurrent purulent eye discharge and frequent watering from both eyes. During infancy the baby had difficulty in feeding. On examination, the child was happy and easy going, had microcephaly (OFC: $42 \mathrm{~cm}$, expected: $47.5 \mathrm{~cm}$ ), short stature (height: $70 \mathrm{~cm}$, expected: $92 \mathrm{~cm}$ ), mental retardation. Typical facial features included broad forehead, frontal hair up-sweep, pointed beaked nose, highly arched eyebrows, micrognathia, high arched palate, low-set deformed ears, bilateral pits on the posterior aspect of helix, short neck, downward slanting of palpebral fissures. Examination of hands and feet revealed broad thumbs and great toes with radial deviation of thumbs, post axial polydactyly in lower limbs, persistent fetal fingertip pads, fifth finger clinodactyly, syndactyly between great toe and $2^{\text {nd }}$ toe of left lower limb. Echocardiographies, USG abdomen, EEG, X-ray spine, ophthalmological examination were normal. There was no family history of similar disease and parents were apparently normal. Among the

\section{Address for correspondence}

Dr. Nabanita Das

MBBS, MD Resident,

Department of Paediatrics

R.G Kar Medical College, Kolkata, West Bengal, India.

E-mail: nabnita.das986@gmail.com

\section{Abstract}

Rubinstein Taybi is a rare genetic syndrome with characteristic facial features, broad thumb and toes, mental retardation. Diagnosis is mainly clinical. Here we report a 2 and $1 / 2$ year old female child with typical facial features and other anomalies characteristics of Rubistein Taybi syndrome. Among the different features described-polydactyly, syndactyly, micrognathia are occasional abnormalities to be found in this syndrome. Bilateral pits on posterior aspect of helix is also a feature described in very few literatures.

different features described-polydactyly, syndactyly, micrognathia are occasional abnormalities to be found in this syndrome ${ }^{3}$. Bilateral pits on posterior aspect of helix is also a feature described in very few literatures.

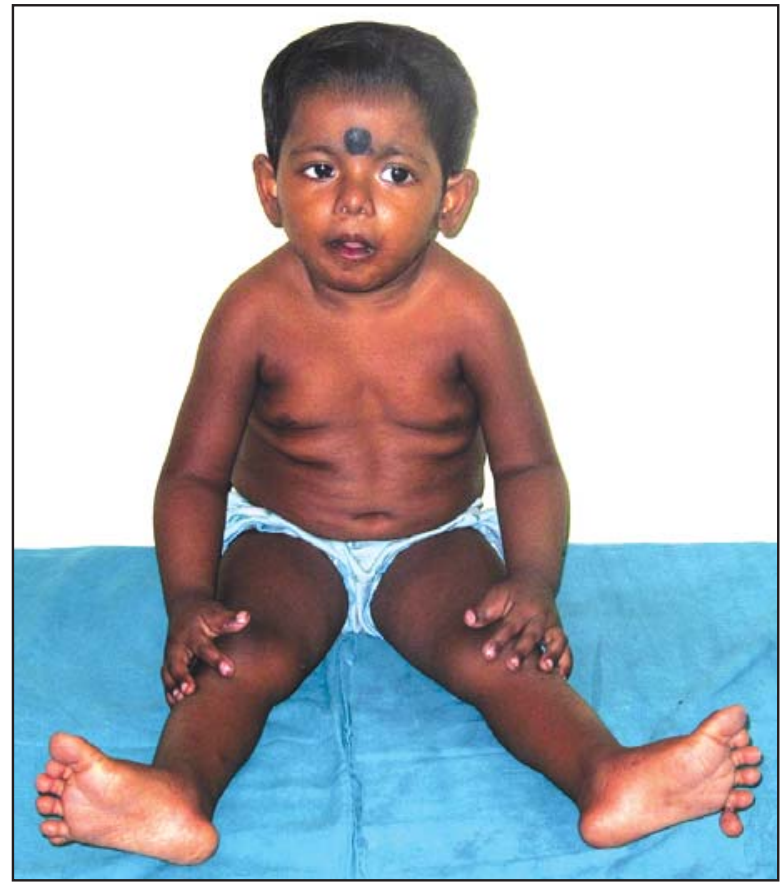

Fig 1: Showing patient having typical facies, post axial polydactyly,broad and radialy deviated thumb. (The mark in the middle of forehead is not a skin lesion but a religious tika) 


\section{Discussion}

Diagnosis of RTS is still clinical ${ }^{4}$. Majority of cases are sporadic. It can also be caused by microdeletion of 16p13.3 or by mutation in either CRE B-binding protein (CBP) or E1Abinding protein (p300). About $4-25 \%$ cases are due to microdeletion detectable by $\mathrm{FISH}^{3}$. However Clinical features are usually same in those with or without deletion with possible exceptions of microcephaly, angulation of fingers and partial duplication of halluces which are more common in those with microdeletion. Cyclic-AMC-regulated enhancer (CRE) binding protein, or CREB binding protein, is generally referred to as CBP. CBP has a homolog, $p 300$, located at chromosome 22q13; both are similar in structure and function $^{5}$ : both act as transcriptional co-activators and act also as potent histone acetyl transferases by making the DNA accessible to transcription factors ${ }^{6}$. They are mediators of signaling pathways and participants in basic cellular functions such as DNA repair, cell growth, cell differentiation, apoptosis, and tumor suppression.

Continuing research eventually led to the demonstration of mutations in the causative $C B P$ gene. Combining the results of larger studies ${ }^{7}$, a CBP mutation was found in 63 of 155 patients (41\%). Subsequent studies showed mutations in $p 300$ in a limited number of individuals ${ }^{7}$. The true frequency of $p 300$ mutations remains uncertain. At present it remains uncertain whether there is yet another cause of Rubinstein-Taybi syndrome.

\section{Conclusion}

An early diagnosis is critical both for the parental information and for management of the medical problems. Adequate counseling of parent include first properly formulated information regarding the disease itself. Regarding recurrence, in sibling recurrence risk 0.1 percent ${ }^{7}$. These children can reproduce, and recurrence risk in their offsprings is 50 percent $^{8}$. These patient have increased risk of certain tumor mainly meningioma, brain tumors, and leukemia. Life expectancy seems to be normal. As these patients are mainly asymptomatic, most of them remain undiagnosed.

\section{References}

1. Rubinstein $\mathrm{JH}$, Taybi $\mathrm{H}$ : Broad thumbs and toes and facial abnormalities. Am J Dis Child 1963;105:588608.

2. Hennekam RCM: Rubinstein-Taybi syndrome. Eur J Hum Genet 2006;14:981-985.

3. Jones KL: Smith's Recognizable Patterns of Human malformation. Rubinstein-Taybi Syndrome. $6^{\text {th }}$ ed.Saunders Elsevier p88-89.

4. Hennekam R.C.M: Rubinstein-Taybi syndrome. Eur J Hum Genet 2006;14:981-98.

5. Arany Z, Sellers WR, Livingston DM, Eckner R: E1A-associated p300 and CREB-associated CBP belong to a conserved family of coactivators. Cell 1994;77:799-800.

6. Bannister AJ, Kouzarides T: The CBP co-activator is a histone acetyltransferase. Nature 1996;384:64143.

7. Jeroen H. Roelfsema, Stefan J. White, Yavuz Ariyürek, Deborah Bartholdi, Dunja Niedrist, Francesco Papadia,et.al: Am J Hum Genet 2005;76(4):572-80.

8. Hennekam RCM, Stevens CA, Van de Kamp JJ: Etiology and recurrence risk in Rubinstein-Taybi syndrome. Am J Med Genet Suppl 1990;6:56-64. 